\title{
FAKTOR - FAKTOR YANG MEMPENGARUHI NIAT UNTUK BERTRANSAKSI SECARA ONLINE PADA TOKO ONLINE
}

\author{
Dwi Islamiyati \\ Nugraeni* \\ Fakultas Ekonomi \\ Universitas Mercu Buana Yogyakarta \\ *nda_eni@yahoo.com
}

\begin{abstract}
This study aims to determine the effect of privacy, security, trust, and experience the internet on the intention to transact online. The study subjects were 200 students from various colleges in the city of Yogyakarta. The research method was a questionnaire survey instrument. Analysis of the data used is test convergent validity, discriminant and composite reliability test. Results showed that :There is the influence of trust and perceptions of risks to attitude. There is influence between security, trust and privacy to the perception of risk. There is the influence of attitudes and perceptions of risk on the intention to transact online. There is a relationship between the experience of using the internet and subjective norm on the intention to transact online. There is a positive effect between behavioral control on the intention to transact online.
\end{abstract}

Keywords : Privacy, Security, Trust, Internet experience, Intention, and online transactions

\section{PENDAHULUAN}

Saat ini banyak orang yang menggunakan komputer dan internet untuk berbelanja. Aneka informasi yang diperoleh telah mengubah cara mereka bertransaksi berbagai macam barang atau jasa. Internet merupakan media untuk berkomunikasi antara perusahaan dengan konsumen. Hampir tiap website meminta identitas pribadi seperti nama pelanggan, alamat $e$ mail, nomor telepon, atau alamat surat. Pengguna sadar bahwa penjual berusaha menjejaki data seperti produk yang dibeli, metode pembayaran yang digunakan, nomer kartu kredit, pilihan produk dan sejarah transaksi dikumpulkan, disimpan dan dianalisis oleh sistem e-bisnis dan yang kemudian digunakan mengevaluasi perilaku pembelian. E-vendor menggunakan informasi ini untuk menjual, mempromosikan produk baru secara langsung melalui $e$-mail pribadi pelanggan. Ketika pelanggan kembali pada website yang pernah digunakan untuk melakukan pembelian, angka-angka kartu keredit dan alamat pengiriman sudah ada tersedia. Pengumpulan data pribadi untuk mengevaluasi kebutuhan pelanggan dan meningkatkan layanan, tetapi dalam penggunaan internet ancaman pelanggaran sanggat tinggi. Perpindahan data pribadi antar internet menjadi perhatian konsumen (Liu et al., 2004).

Untuk mengembangkan suatu kerangka adopsi e-commerce integratif, the theory planned behavior (TPB), seperti yang diusulkan oleh (Ajzen 1991) digunakan sebagai pendekatan dalam penelitian ini. The theory planned behavior menyatakan bahwa perilaku ditentukan oleh niat. Niat dibentuk oleh sikap, norma subjektif dan kontrol prilaku. Sikap, terbentuk oleh kepercayaan. Variabel niat adalah kesediaan konsumen untuk bertransaksi secara online. Sasaran penelitian ini adalah untuk mengidentifikasi faktor yang berperan untuk kesediaan, atau tujuan konsumen untuk bertransaksi secara online. 
Sasaran lain dari penelitian ini adalah menguji pengaruh antara privasi kepercayaan, keamanan, serta pengalaman. Mayer, dan Davis (1995) mengusulkan suatu model kepercayaan yang menguraikan secara singkat kondisi-kondisi manakala kepercayaan terjadi. Dalam penelitian ini, fokus pada awal kepercayaan atau tidak ada hubungan antara konsumen dan toko online. Kepercayaan dan resiko dalam the theory planned behavior, akan manjadi konsep dalam penelitian ini sebagai keyakinan yang berdampak pada niat untuk bertransaksi secara online. Kepercayaan berhubungan pada konsumen untuk percaya bahwa toko online mampu untuk melaksanakan transaksi dan melindungi informasi pribadi konsumen. Persepsi resiko mengacu pada ketidak pastian yang mungkin ditemui oleh konsumen dalam memberikan informasi pribadi pada toko online.

Faktor penting lainnya adalah pengalaman menggunakan Internet. Pengalaman menggunakan Internet merupakan pertimbangan penting dalam melakukan pembelian secara online (Hoffman et al., 1999). Hoffman menemukan bahwa perhatian konsumen terhadap pengendalian informasi pribadi ternyata meningkatkan pengalaman akan internet, sebaliknya perhatian pada hambatan fungsional untuk belanja secara online menurun. Pengguna internet yang belum berpengalaman, biasanya jarang bertransaksi secara online: $27 \%$ pengguna dengan pengalaman kurang dari 6 bulan pernah bertransaksi sesuatu melalui internet, dibanding dengan $60 \%$ mereka yang berpengalaman 3 tahun lebih dalam menggunakan internet (Fox, 2000). Sebagai tambahan, pengguna baru lebih takut dengan masalah pencurian kartu kredit $(70 \%)$ dari pada pengguna internet berpengalaman. (46\%) (Fox, 2000).

\section{LANDASAN TEORI PENGEMBANGAN HIPOTESIS}

DAN

Peneliti bidang e-commerce telah mempelajari kepercayaan pada konteks $e$ commerce (Gefen et al., 2003). Mayer et al.,
(1995) mengusulkan suatu definisi kepercayaan integratif sebagai "kesediaan dari suatu pihak untuk peka kepada tindakan pihak lain yang didasarkan pada harapan pada pihak yang dipercayai akan melaksanakan tin

bagi trustor, tanpa tergantung dengan kemampuan untuk memonitor atau mengendalikan pihak yang dipercayai. Dalam e-commerce, konsumen adalah trustor sedang toko online adalah pihak yang dipercayai. Konsumen harus peka kepada tindakan dari toko online karena menyediakan informasi sensitip seperti informasi kartu kredit, alamat dan e-mail manakala mereka berniat untuk bertransaksi elektronik. Konsumen hanya membatasi kemampuan untuk memonitor tindakan toko online mengenai penggunaan yang tidak sah dari informasi pribadi, karenanya, ada suatu keengganan yang tidak bisa dipisahkan oleh pihak konsumen untuk membagi bersama informasi pribadi mereka. Karena itu, kepercayaan diperlukan untuk membebaskan perhatian konsumen (Luo, 2002).

Dalam literatur, kepercayaan menjadi konsep sebagai kepercayaan, sikap, perilaku dan niat (Mayer et al., 1995). Kepercayaan menjadi status psikologis, dengan jelas nyata dari perilaku, melainkan adalah suatu antecedent perilaku (Bhattacherjee, 2002). Dimensi kepercayaan yang diuraikan oleh Bhattacherjee (2002) adalah kemampuan, kebajikan dan integritas. Kemampuan mengacu pada persepsi konsumen, kemampuan dan pengetahuan perilaku yang diharapkan dari toko online. Persepsi ini mungkin diakibatkan oleh pengalaman masa lalu atau pengesahan kelembagaan dari pihak ketiga. Dalam format kepercayaan integritas mengacu pada persepsi konsumen pada toko online akan bertahan pada satu prinsip atau peraturan tentang pertukaran yang bisa diterima konsumen selama mengikuti pertukaran. Kebajikan adalah tingkat suatu toko online bertindak atas nama kesejahteraan konsumen.

Dalam sistem e-commerce, kepercayan pengguna tentang suatu toko online mungkin ditangkap oleh kepercayaan dan persepsi 
resiko. Sikap salah satu yang baik atau kurang baik. Suatu sikap yang baik akan membentuk niat untuk betransaksi secara online, kemudian diikuti oleh niat perilaku nyata dalam membeli dari toko online. Kepercayaan dibentuk oleh konsumen yang didasarkan pada informasi yang tersedia tentang toko online. Kepercayaan pada suatu toko online dapat menghasilkan suatu sikap yang baik oleh konsumen dan mungkin juga meningkatkan sikap secara tidak langsung dengan menurunkan persepsi resiko (Jarvenpaa et al., 1999).

H1: Kepercayaan berpengaruh terhadap sikap konsumen untuk bertransaksi secara online

Suatu penelitian yang telah menguji hubungan keamanan, persepsi resiko dan niat bertransaksi secara online. Dalam Banyak kasus, keamanan telah dimasukkan sebagai bagian dari privasi. Dalam penelitian ini informasi privasi menggunakan instrumen yang dikembangkan oleh Smith et al., (1996). Empat dimensi dalam informasi pribadi adalah pengumpulan, kesalahan, penggunaan tidak sah dan akses yang tidak pantas. Empat dimensi, akses tidak pantas nampak sama yang dikenal sebagai kontrol lingkungan, yang berhubungan erat pada keamanan Hoffman et al., ( 1999).

Studi empiris sangat terbatas pada keamanan, Miyazaki dan Fernandez (2001) menemukan keamanan sistem dihubungkan dengan tingkat tarip dari produk online yang dibeli oleh konsumen. Bagaimanapun, tidak ada hubungan negatif antara kehadiran statemen keamanan dan privasi dan resiko yang ditemukan (Miyazaki dan Fernandez 2001). Dalam studi yang sama, keamanan dan privasi secara positif dihubungkan dengan kemungkinan pembelian secara online. Pengujian peran persepsi resiko dalam hubungan antara keamanan dan privasi berhubungan dengan dan niat bertransaksi secara online, Miyazaki dan Fernandez (2001).

H2: Keamanan berpengaruh terhadap persepsi resiko.
Dalam literatur pemasaran kerangka teoritis resiko sebagai perilaku konsumen. Menurut kerangka kerja resiko, konsumen memutuskan untuk membeli suatu produk di bawah derajat tingkat ketidak pastian tentang toko online. Untuk mengurangi persepsi resiko konsumen bertindak untuk mengasumsikan resiko yang dirasa, dengan mempercayakan atas seseorang atau gagasan dari pihak ketiga. Sebagai Contoh, suatu konsumen mungkin bersandar pada gambaran merek dari suatu produk atau pada pendapat dari orang yang ahli. Persepsi resiko digunakan sebagai suatu pengganti resiko karena sukar untuk menangkap resiko sebagai suatu sasaran yang pasti. Persepsi resiko digambarkan sebagai kemungkinan hubungan suatu kerugian dalam pengejaran suatu hasil yang diinginkan. Malhotra et al., ( 2004), menetapkan literatur resiko kepercayaan menjadi ciri pribadi mempengaruhi kepercayaan dan persepsi resiko (Mayer et al., 1995). Jika konsumen terlalu memperhatikan privasi akan mempengaruhi bagaimana dia akan mempercayai suatu online vendor, atau resiko yang dirasa dalam pembelian dari online vendor.

\section{H3: Kepercayaan berpengaruh terhadap persepsi resiko.}

Secara umum privasi mengacu pada perlindungan informasi pribadi. Chau., et al (1999) mendefinisikan adalah hak individu untuk menjadikan dirinya sendiri dengan mempertimbangkan beberapa dimensi privasi seperti, prilaku, komunikasi, dan data pribadi. Dalam internet, privasi mempengaruhi aspek seperti distribusi, atau penggunaan non-autorised informasi pribadi (Wang et al., 1998). Kapasitas pertumbuhan teknologi baru untuk mengolah informasi, plus kompleksitas menjadikan privasi isu penting. Fakta ini semakin meningkatkan kecurigaan konsumen seperti bagaimana data pribadi dikumpulkan diproses dalam transaksi online (Flavio dan Gunalu, 2006). Untuk mengurangi kecurigaan konsumen mengenai penanganan data pribadi keamanan sistem sangat penting yang dapat 
menjamin kemanan data pribadi. Oleh sebab itu hipotesa berikut.

\section{H4: Privasi berpengaruh terhadap persepsi resiko}

Persepsi Resiko dipandang sebagai ketidak pastian dihubungkan dengan hasil dari suatu keputusan. Dalam literatur $e$ commerce, ada dua kategori resiko yaitu: resiko transaksi dan resiko produk (Chang et al., 2005. Resiko produk mengacu pada ketidak-pastian pembelian akan memenuhi penerimaan pengukuran dalam hasil atau tujuan pembelian. Sitkin dan Pablo (1992) mengusulkan resiko yang dirasa mungkin memediasi dampak kepercayaan pada perilaku dan niat. Beberapa peneliti menginvestigasi dampak kepercayaan pada resiko yang dirasa.

Suatu dampak negatif penting antara kepercayaan dan resiko yang dirasakan terhadap sikap (Jarvenpaa et al., 2000).

\section{H5: Persepsi resiko berpengaruh terhadap sikap konsumen untuk bertransaksi secara online.}

Sikap terhadap perilaku merupakan evaluasi positif atau negatif dalam melakukan perilaku.Dalam sistem $e$ commerce, kepercayaan pengguna tentang suatu toko online mungkin ditangkap oleh kepercayaan dan persepsi resiko. Sikap salah satu yang baik atau kurang baik. Suatu sikap yang baik akan membentuk niat untuk bertransaksi secara online, kemudian diikuti oleh niat perilaku nyata dalam membeli dari toko online. Kepercayaan dibentuk oleh konsumen yang didasarkan pada informasi yang tersedia tentang toko online. Kepercayaan pada suatu toko online dapat menghasilkan suatu sikap yang baik oleh konsumen dan mungkin juga meningkatkan sikap secara tidak langsung dengan menurunkan persepsi resiko (Jarvenpaa et al., 1999).

H6: Sikap berpengaruh terhadap niat konsumen untuk bertransaksi secara online.
Persepsi Resiko didefinisikan sebagai persepsi konsumen atas ketidakpastian dan konsekuensi yang akan dihadapi setelah melakukan aktifitas tertentu (Dowling and Steling dalam Hsu dan Chiu, 2002). Bila diadaptasikan dengan konteks penelitian persepsi resiko adalah persepsi pengguna internet sebagai individu terhadap ketidakpastian dan konsekuensi yang dihadapi saat menggunakan transaksi online, karena penggunaan transaksi online tidak terlepas dari resiko.Resiko yang dapat dihadapi oleh pengguna transaksi online adalah resiko keamanan bertransaksi dan kepastian terhadap barang yang dipesannya. Persepsi terhadap resiko diprediksi akan berpengaruh negatif terhadap niat individu untuk bertransaksi secara online.

Menurut Pavlou dan Geven (2004), bila persepsi resiko semakin besar, maka niat untuk bertransaksi onlineakan berkurang. Oleh karena itu hipotesa yang terbentuk.

Hipotesa 7: Persepsi resiko berpengaruh terhadap niat individu untuk melakukan bertransaksi secara online.

Venkatesh dan Davis (1996), dalam pengembangan TAM yang memfokuskan pada variabel awal dari kemudahan penggunaan, secara teoritis menyatakan bahwa pengalaman langsung dengan perangkat lunak menjadi perantara dalam hubungan langsung antara tujuan penggunaan dankemudahan penggunaan.

Dalam penelitian terbaru, antecedent dari kemudahan penggunaandalam TAM, Venkatesh (2000) menemukan bahwa pengalamantidak memerankan peranan sebanyak peranannya seperti yang diharapkan dalam menjelaskan varian dalam kemudahan penggunaan disadari. Kepercayaan pada general sistem independenttentang komputer lebih menjadi peramal yang lebih kuat dari kemudahan penggunaan disadaridari pada pengalaman, selama tiga periode. Dengan menggunakan the theory planned behavior, Taylor dan Todd (1995) menyelidiki perbedaan antara mahasiswa yang berpengalaman dan tidak berpengalaman dari sebuah pusat studi 
komputer. Mereka menemukan hubungan yang lebih kuat antara perilaku niatdan perilaku aktualbagi pemakai yang berpengalaman, dibanding pemakai yang tidak berpengalaman. Mereka juga menemukan bahwa niat dari pemakai yang tidak berpengalaman lebih mudah diramalkan oleh variabel awal dari pada kasus untuk pemakai yang berpengalaman.

H8: Pengalaman seseorang menggunakan internet berpengaruh terhadap niat untuk bertransaksi secara online.

Dalam the thoeri planned behavior, norma subjektif adalah suatu perilaku yang digambarkan sebagai suatu penilaian ya atau tidak bagi orang yang merasakan perilaku harus dilakukan (Ajzen 1991). Penilaian ini dilakukan sejumlah referents yang relevan seperti, teman, keluarga dan co-workers. Kepercayaan berdasarkan pengukuran norma subjektif yang terdiri dari motivasi dan kepercayaan berdasarkan norma subjektif. Kepercayaan berdasarkan norma subjektif mengacu pada penilaian bagaimana mungkin atau mau tidak mau kelompok referent mendukung perilaku. Motivasi untuk mematuhi mengacu pada penilaian pribadi bagaimana yang termotivasi untuk memenuhi ketentuan kelompok referent.The theory planned behavior menyarankan suatu hubungan positif antara hubungan norma subjektif dan niat prilaku.

H9: Norma subjektif berpengaruh terhadap niat untuk bertransaksi secara online.

Kontrol perilaku mempunyai suatu hubungan positif antara niat dan perilaku yang nyata. Menurut Ajzen (1991), kontrol prilaku berhubungan dengan bagaimana sulit atau gampang untuk menyelesaikan suatu perilaku tertentu. Kontrol prilaku menandakan suatu derajat hubungan kontrol atas capaian dari suatu perilaku dibanding kemungkinan suatu perilaku akan mengakibatkan suatu hasil tertentu (Ajzen 2002). Penelitian ini, merasa kontrol prilaku digambarkan sebagai suatu kesukaran atau kesenangan konsumen yang dirasa di dalam pembelian dari toko onlline.

H10: Kontrol perilaku berpengaruh terhadap niat untuk bertransaksi secara online.

\section{METODOLOGI PENELITIAN \\ Pengumpulan data dan pengambilan sampel}

Populasi dalam penelitian ini adalah mahasiswa Yogyakarta pengguna internet. Metode pengambilan sampel yang digunakan adalah non probability dengan tehnik pengambilan sampel adalah purposive samplingdengan kriteria yaitu individu yang menggunakan internet dan mengerti situssitus yang menawarkan fasilitas penjualan secara online, serta belum pernah melakukan transaksi secara online.

\section{Definisi Operasional variabel}

Privasi suatu individu dalam konteks $e$ commerce dipengaruhi oleh kondisi-kondisi eksternal (yaitu: sektor industri, kultur, hukum) seperti halnya kondisi eksternal persepsi individu. Privasi diukur skala likert 1 sampai dengan 5.Variabel persepsi diukur dengan menggunakan 4 item pertanyaan yang diadaptasi dari Malhotra et al., (1994).

Keamanan mengacu pada tingkat orang percaya informasi pribadi yang dipancarkan internet dijamin dan tidak akan diakses oleh orang lain. Variabel keamanan diukur menggunakan skala likert 1 sampaidengan 5 . Variabel keamanan diukur dengan menggunakan 4 item pertanyaan yang diadaptasi dari Salisbuty et al., (2001).

Dimensi kepercayaan adalah kemampuan, integritas dan kebajikan.Variabel kepercayaan diukur menggunakan skala likert 1 sampai dengan 5. Variabel kepercayaan diukur dengan menggunakan 3 item pertanyaan yang diadaptasi dari Bhattacherjee (2002).

Persepsi Resiko mengacu pada ketidak pastian konsumen yang dirasakan untuk memutuskan untuk bertransaksi secara online. Variabel persepsi resiko diukur menggunakan skala likert 1 sampai dengan 5. Variabel persepsi resiko diukur dengan 
menggunakan 3 item pertanyaan yang diadaptasi dari Jarvenpaa et al., (1999).

Sikap adalah suatu tindakan yang ditunjukan oleh individu untuk menggambarkan suka atau tidak suka terhadap suatu objek.Variabel sikap diukur menggunakan skala likert 1 sampai dengan 5.Variabel sikap diukur dengan menggunakan 2 item pertanyaan yang diadaptasi dari Pavlou dan Fygenson ( 2005).

Norma subjektif mengacu pada persepsi konsumen apakah suatu perilaku tertentu diterima oleh suatu kelompok referensi Variabel norma subjektif diukur menggunakan skala likert 1 sampai dengan 5. Variabel norma subjektif diukur dengan menggunakan 2 item pertanyaan yang diadaptasi dari Pavlou dan Fygenson (2005).

Kontrol perilaku digambarkan sebagai persepsi dari suatu individu mengenai sulit atau tidaknya individu untuk menyelesaikan suatu tugas tertentu.Variabel kendali perilaku diukur menggunakan skala likert 1 sampai dengan 5. Variabel kendali prilaku diukur dengan menggunakan 2 item pertanyaan yang diadaptasi dari Pavlou dan Fygenson (2005).

Niat adalah kesediaan konsumen untuk membeli dari toko online. Variabel niat diukur menggunakan skala likert 1 sampai dengan 5. Variabel niat diukur dengan menggunakan 2 item pertanyaan yang diadaptasi dari Malhotra et al., (2005).

Peranan pengalamanjuga telah diteliti dalam literatur sistem informasi dalam bidangpenerimaan pengguna, dimana The Theoryreasoned action dan Theory planned behavior telah diterapkan dalam pengembangan. Variabel pengalaman diukur menggunakan skala likert 1 sampai dengan 5. Variabel pengalaman diukur dengan menggunakan 2 item pertanyaan yang diadaptasi dari Thomson (2005).

\section{Model Penelitian}

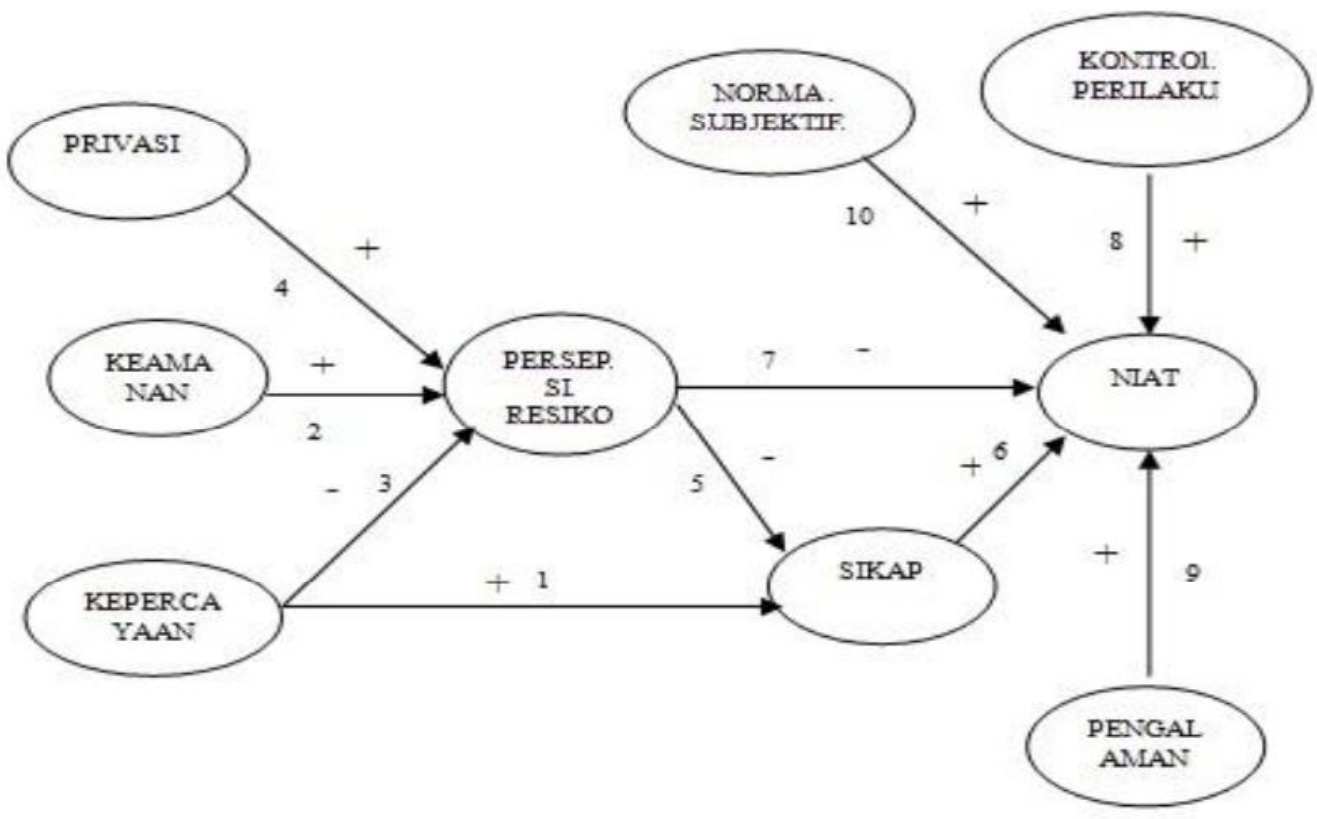

\section{Teknik analisis data}

Untuk menjawab hipotesis yang diajukan diuji dengan menggunakan partial least-square (PLS),terdiri atas 2 macam pengujian, yaitu model pengukuran (outer model) dan struktural model (inner
model).Pengujian Inner Model dilakukan untuk melihat hubungan antara konstruk dan nilai signifikansinya serta nilai $R$-square. Nilai $R$-square digunakan untuk menilai pengaruh variabel independen terhadap variabel dependen apakah mempunyai 
pengaruh yang subtantif. Berikut akan oleh variabel dependen kepercayaan, disajikan Tabel nilai $R$-square.

persepsi resiko sebesar 0,553.Selain menilai inner model juga melihat hubungan antara

Tabel 1

\begin{tabular}{cc}
\multicolumn{2}{c}{ R-square } \\
\hline & R-square \\
\hline NIAT & 0,748 \\
PERSEPSI RESIKO & 0,753 \\
SIKAP & 0,553 \\
\hline
\end{tabular}

Model memberikan nilai $R$-square sebesar 0,748 pada veriabel niat yang berarti bahwa variabel niat dapat dijelaskan oleh variabel persepsi resiko, sikap, norma subjektif, kontrol prilaku dan pengalaman terhadap variabel niat sebesar 0.748 . Sementara itu variabel perspesi resiko dapat dijelaskan oleh variabel dipenden yaitu privasi, keamanan, dan kepercayaan sebesar 0,753 Serta variabel sikap dapat dijelaskan konstruk laten dengan memperhatikan hasil estimasi koefesien parameter path dan tingkat signifikansinya.

\section{Hasil Uji Hipotesis}

Dari Pengolahan data, pengujian hipotesis dapat dilakukan dengan memperhatikan tingkat signifikansinya dan parameter path antara variabel laten. Hipotesis yang diajukan untuk mengetahui hubungan masing-masing konstruk yang dihipotesiskan. Gambar 2 menunjukan hubungan yang bervariasi. Hubungan positif terjadi pada semua hubungan antar konstruk dengan nilai korelasi yang bervariasi. Sedangkan hubungan negatif hanya terjadi pada hubungan persepsi resiko terhadap niat untuk bertransaksi secara online.

\section{Gambar 1}

\section{Korelasi antar konstruk}

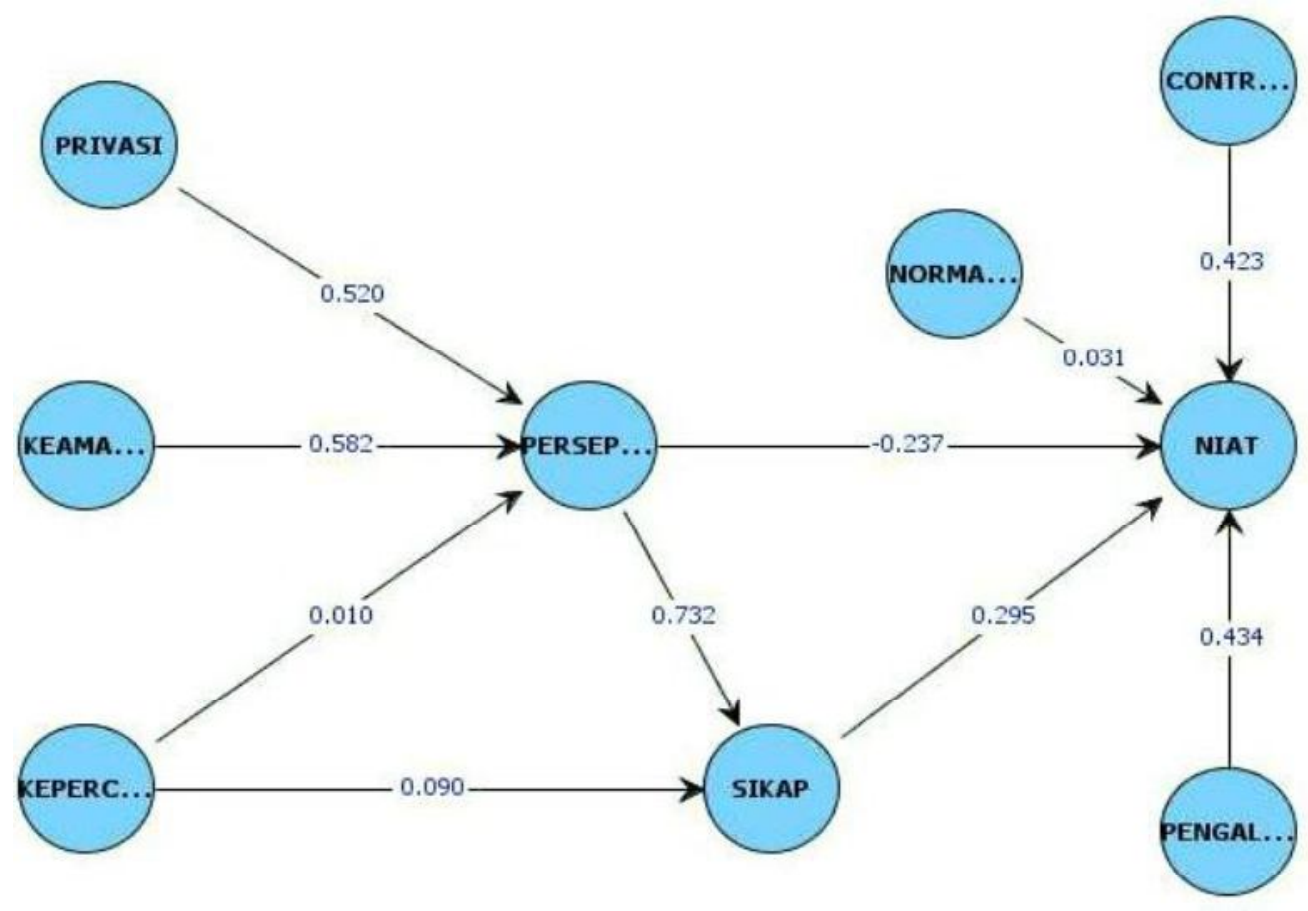

Pengambilan keputusan didasarkan pada arah hubungan dan signifikansi dari model

pengujian dan korelasi antar konstruk yang ditunjukan pada Tabel 2 
Tabel 2

Signifikasi Hubungan Antar Variabel

\begin{tabular}{|c|c|c|c|c|}
\hline Hipotesis & Korelasi & $\begin{array}{l}\text { Rata-rata } \\
\text { sub } \\
\text { sampel }\end{array}$ & $\begin{array}{l}\text { Standar } \\
\text { Deviasi }\end{array}$ & t-statistik \\
\hline $\begin{array}{l}\text { Hipotesis 1: Kepercayaan berpengaruh positif } \\
\text { terhadap sikap konsumen untuk bertransaksi secara } \\
\text { online }\end{array}$ & 0,090 & 0,102 & & $1,1: 8$ \\
\hline $\begin{array}{l}\text { Hipotesis 2: Keamanan secara positif berpengaruh } \\
\text { terhadap persepsi resiko, }\end{array}$ & & 48 & & 5862 \\
\hline $\begin{array}{l}\text { Hipotesis 3:Kepercayaan berpengaruh negatif } \\
\text { terhadap persepsi resiko, }\end{array}$ & & 1 & & 10 \\
\hline $\begin{array}{l}\text { Hipotesis 4:Privasi berpengaruh positif terhadap } \\
\text { persepsi persepsi resiko }\end{array}$ & & 96 & 0,113 & \\
\hline $\begin{array}{l}\text { Hipotesis 5:Persepsi resiko berpengaruh negatif } \\
\text { terhadap sikap konsumen untuk bertransaksi } \\
\text { secara online, }\end{array}$ & 0,832 & & $0 \times 8$ & 8,288 \\
\hline $\begin{array}{l}\text { Hipotesis 6:Sikap berpengaruh positif terhadap } \\
\text { niat konsumen untuk bertransaksi secara online, }\end{array}$ & 0,295 & 0,270 & & $24 \%$ \\
\hline $\begin{array}{l}\text { Hipotesis 7: Persepsi resiko berpengaruh negatif } \\
\text { terhadap niat untuk bertansaksi secara online }\end{array}$ & $-0,237$ & - & 0,268 & 1,658 \\
\hline $\begin{array}{l}\text { Hipotesis 8:Pengalaman menggunakan internet } \\
\text { secara positif berpengaruh terhadap niat untuk } \\
\text { bertransaksi secara online }\end{array}$ & 0,434 & 0,427 & & $300 !$ \\
\hline $\begin{array}{l}\text { Hipotesis 9:Norma subjektf berpengaruh positif } \\
\text { terhadap niat untuk bertransaksi secara online, }\end{array}$ & 0,031 & & $0,3 \mathbf{i}$ & 0,339 \\
\hline $\begin{array}{l}\text { Hipotesis 10: Kontrol prilaku berpengaruh positif } \\
\text { terhadap niat untuk bertransaksi secara online }\end{array}$ & & 25 & & 34.26 \\
\hline
\end{tabular}

\section{SIMPULAN}

Terdapat pengaruh antara kepercayaan dan persepsi resiko terhadap sikap.Terdapat pengaruh antara keamanan, kepercayaan dan privasi terhadap persepsi resiko.Terdapat pengaruh antara sikap dan persepsi resiko terhadap niat untuk bertransaksi secara online.Terdapat hubungan antara pengalaman menggunakan internet dan norma subjektif terhadap niat untuk bertransaksi secara online.Terdapat pengaruh yang positif antara kontrol prilaku terhadap niat untuk bertransaksi secara online.

\section{Keterbatasan dan Rekomendasi Penelitian Berikutnya}

Penelitian ini memiliki beberapa keterbatasan yang mungkin dapat mempengaruhi hasil penelitian, antara lain:
1. Indikator mengalami pengalih responden memiliki persepsi yang berbeda terhadap persepsi peneliti.

2. Data yang dianalisis dalam penelitian ini dikumpulkan dengan metode survei, yang mengandung kelemahan yaitu kemungkinan tidak tercerminkan keadaan sesungguhnya. Hal ini dikarenakan responsden yang tidak serius dalam mengisi kusioner, sehingga kemungkinan dapat menimbulkan hasil yang bias atau menyesatkan.

3. Sampel terbatas pada mahasiswa sistem informasi, oleh karena itu sebagian besar responden sangat terdidik dengan baik dan berpengalaman menggunakan internet.

Dari hasil analisis dan kesimpulan serta keterbatasan penelitian, maka saran untuk penelitian selanjutnya:

1. Penelitian selanjutnya dapat menggunakan sampel yang lebih besar dari kalangan profesional, sehingga 
akan menghasilkan kondisi yang sebenarnya dan respresentatif.

2. Penelitian selanjutnya dapat dilakukan dengan mengembangkan model ini dengan menabahkan variabel lain yang belum digunakan dalam penelitian ini seperti serivice quality, product category, income dan informasi mengenai web vendor.

\section{DAFTAR PUSTAKA}

Ajzen,I.(1985)."FromIntentionstoActions:A TheoryofPlannedBehavior."Action Control:

FromCognitiontoBehavior,J.Kuhlan dJ.Beckman,eds.,SpringerVerlag, Ne wYork,11-39.

Ajzen,I.(1991)."TheTheoryofPlannedBehav ior."OrganizationalBehaviorandHu manDecisionProcesses,50(2),179211.

Gefen,D.,Karahanna,E.,andStraub,D.W.(20 03)."TrustandTAMinOnlineShoppin g:AnIntegratedModel."MISQuarterl $y, 27(1), 51-90$.

Ghozali,Imam.SrtrukturalEquationModelin gMetodeAlternatifdenganPartialLea stSquareBadanPenerbitUniversitas Diponegoro2006

Hartono,Jogiyanto, Metodelogi PenelitianBisnis:SalahkaprahdanPe ngalaman-pengalaman, BPFEUGM,2004

Hoffman, D.L., Novak, T.P. and Peralta, M. 1999. Building consumerTrust
onlineCommunicationsoftheACM.V ol.42No.4. h.80-5.

Pavlou,P.A.(2002)."Institution-based trustininterorganizationalexchanger elationships:the roleofonlineB2Bmarketplacesontrus tformation." TheJournalofStrategic InformationSystems, 11(3-4),215243.

Pavlou,P.A.,andFygenson,M.(2006)."Under standingandPredictingElectronicCo mmerceAdoption:AnExtensionofthe TheoryofPlannedBehavior."MISQu arterly,30.

Phelps,J.,Nowak,G.,andFerrell,E.(2000)."Pr ivacy

concernsandconsumerwillingnessto providepersonalinformation."Journ alof

PublicPolicy\&Marketing,19(1),2741.

Smith, H. J., Milberg, S. J., andBurke, S. J. (1996). "Information privacy: Measuring individuals'concernsaboutorganizati onalpractices."MISQuarterly,20(2), 167-196.

Szanja,B.1996.Empiricalevaluationoftherev isedtechnology acceptancemodel.ManagementScience.Vol.42No.1.h.85-92.

Taylor,S.,andTodd,P.A.(1995)."Understand ingInformationTechnologyUsageaTestofCompetingModels."Informat ionSystemsResearch,6(2),144-176.

Wangetal.,1998,“Consumerprivacyconcern saboutinternetmarketing ,Commun ication of theACM,Vol.41,pp.63-70 